\title{
Zmartwychwstanie Pańskie w norbertańskim rękopisie „Kontemplacyja męki i śmierci Chrystusa Pana [...]” (1662)
}

Zmartwychwstanie Chrystusa jest zasadniczym wydarzeniem w historii zbawienia oraz podstawową tajemnicą wiary chrześcijańskiej; stanowi kulminacyjną prawdę wiary w Zbawiciela ${ }^{2}$. Bez tego wydarzenia nie można byłoby zrozumieć powstania oraz ukształtowania się chrześcijaństwa ${ }^{3}$. Dobitnie podkreślił to

${ }^{1}$ Katarzyna Kaczor-Scheitler - adiunkt w Zakładzie Literatury Dawnej i Nauk Pomocniczych Uniwersytetu Łódzkiego. Autorka książek Mistycyzm hiszpański w piśmiennictwie polskich karmelitanek XVII i XVIII wieku (Łódź 2005), Marianna Marchocka a św. Teresa z Avila (Poznań 2009) oraz Perswazja $w$ wybranych medytacjach siedemnastowiecznych z klasztoru norbertanek na Zwierzyńcu (Łódź 2016). Współredaktorka tomów zbiorowych Piśmiennictwo zakonne w dobie staropolskiej (2013) oraz Piotr Skarga - w czterechsetlecie śmierci (2013). Publikowała szkice historycznoliterackie oraz artykuły w czasopismach krajowych i zagranicznych (,Acta Universitatis Lodziensis. Folia Litteraria Polonica”, „Czytanie Literatury. Łódzkie Studia Literaturoznawcze”, „Pamiętnik Literacki”, „Poznańskie Studia Polonistyczne. Seria Literacka”, „Prace Polonistyczne”, „Respectus Philologicus”, „Ruch Literacki”, „Świat i Słowo”, „Świat Tekstów. Rocznik Słupski”, „Analecta Praemonstratensia”, „Communio. Międzynarodowy Przegląd Teologiczny”, „Przegląd Powszechny”, „Studia Monastica”) oraz w tomach pokonferencyjnych i okolicznościowych. Głównym obszarem jej poszukiwań naukowych jest barokowa literatura religijna, w szczególności piśmiennictwo zakonne. W kręgu zainteresowań badawczych znajduje się literatura ascetyczno-mistyczna, medytacyjno-modlitewna i okolicznościowa.

${ }^{2}$ Zob. Katechizm Kościoła katolickiego, Poznań 1994, s. 242, § 989; s. 159, § 638; Katechizm rzymski wedlug uchwaty św. Soboru Trydenckiego dla plebanów ułożony, z rozkazu najprzód Piusa $V$, potem Klemensa XIII po łacinie wydany, na polski język w lat cztery po soborze przez ks. Walentego Kuczborskiego, archidiakona pomorskiego przetlumaczony, teraz zaś z matemi poprawkami i z niektóremi dodatkami przedrukowany, t. 1, Jasło 1866, rozdz. 6, podrozdz. 8-15, s. 62-68.

3 Spośród monumentalnego wykazu publikacji z zakresu teologii poświęconych zmartwychwstaniu Chrystusa zob. m.in. L. Stefaniak, Historyczność Zmartwychwstania Chrystusa w Listach św. Pawta, „Ruch Biblijny i Liturgiczny”, R. 8: 1955, nr 6, s. 306-327; E. Kopeć, Spotkanie św. Pawta z Chrystusem, „Zeszyty Naukowe KUL” 1960, t. 3, z. 1 (9), s. 45-60; Tenże, Historiozbawczy charakter Zmartwychwstania Jezusa Chrystusa, „Roczniki Teologiczno-Kanoniczne” 1977, t. 24, z. 4, s. 107-118; Tenże, Zmartwychwstanie Jezusa Chrystusa jako realny fakt $i$ wydarzenie zbawcze, w: Jezus Chrystus. Historia i tajemnica, red. W. Granat, E. Kopeć, Lublin 1988, Rozprawy Wydziału Teologiczno-Kanonicznego, t. 81, s. 246-277; W. Granat, Zmartwychwstanie 
św. Paweł: „Lecz jeśli zmartwychwstania nie masz, ani Chrystus nie powstał z martwych. A jeśliż Chrystus nie powstał, próżne tedy jest przepowiadanie nasze, próżna jest i wiara wasza" (1 Kor 15,13-14)4.

Wiara $\mathrm{w}$ zmartwychwstanie jest zakorzeniona w świadectwie apostołów, które z kolei jest zachowywane i przekazywane w Kościele. Zmartwychwstanie Chrystusa to nie tylko wyjątkowe wydarzenie w dziejach ludzkości, które miało miejsce i o którym chrześcijanin powinien pamiętać, ale także zdarzenie, które dokonawszy się, trwa z całą mocą zbawienia człowieka ${ }^{5}$.

Relacje o zmartwychwstaniu Pańskim znajdujemy przede wszystkim w ewangeliach. Przedstawienia te oparte są na wcześniejszych tradycjach, które w różny sposób opisywały wydarzenia wielkanocne. Należały do nich przekazy o zmartwychwstaniu, o uwielbieniu, o pustym grobie, o odwiedzinach niewiast i uczniów, o strażnikach przy grobie, o chrystofaniach itd ${ }^{6}$. Korzystający z nich ewangeliści starali się zachować własną perspektywę teologiczną przedstawionych zdarzeń, dążąc przy tym do nadania im chrystologicznego sensu.

Ewangelia św. Marka (Mk 16,1-8) zawiera przedstawienie niewiast u grobu w poranek wielkanocny, angelofanii oraz ucieczki zatrwożonych kobiet, brakuje w niej natomiast świadectw o chrystofaniach. W relacji autora wiadomość o zmartwychwstaniu Jezusa przekazał niewiastom (Marii Magdalenie, Marii - matce Jakuba i Salome) młodzieniec ubrany w białą szatę, który był wysłannikiem Bożym. Ów posłannik-anioł, zwiastując dobrą nowinę w imieniu Boga, wydał kobietom polecenie, by udały się do Galilei i dostarczyły wieści apostołom. Jednak ich przerażenie, wynikające z niezrozumienia Bożych tajemnic, powodowało, że nie przekazały one orędzia anioła ${ }^{7}$. Ewangelia zawiera także wzmiankę o zamiarach namaszczenia ciała Chrystusa oraz informację o wielkości kamienia, który zamykał wejście do grobowca. W chrystologii św. Marka zmartwychwstanie ukazane zostało jako tajemnica, której nie można w pełni pojąć ani przekazać ${ }^{8}$.

W Ewangelii św. Mateusza przytoczone zostało opowiadanie o strażnikach przy grobie $(28,1-15)$ oraz o chrystofanii uwielbionego Pana $(28,16-20)$. Przedstawiony anioł był wyraźnie wysłannikiem samego Boga. O Boskiej wszech-

Jezusa Chrystusa jako wydarzenie zbawcze, w: Jezus Chrystus. Historia i tajemnica, s. 277-293; I. Celary, Prawda o zmartwychwstaniu w przepowiadaniu kaznodziejsko-homiletycznym, „Polonia Sacra”, R. 7 (25): 2003, nr 12/56, s. 125-138; I. Celary, Gtoszenie wiary w zmartwychwstanie Chrystusa zasadniczym celem nowej ewangelizacji, „Wrocławski Przegląd Teologiczny”, R. 11: 2003, nr 1, s. 117-135.

${ }^{4}$ Wszystkie cytaty według wyd.: Biblia w przektadzie ks. Jakuba Wujka z 1599 r., wstęp J. Frankowski, wyd. 5, Warszawa 2000.

${ }_{5}$ Zob. Katechizm Kościoła katolickiego, s. 269, § 1085.

${ }^{6}$ Zob. X. Léon-Dufour, Sur la resurrection de Jésus, „Recherches de science religieuse”, 57 : 1969, s. 583-622. Cyt. za: E. Kopeć, Historiozbawczy charakter Zmartwychwstania ..., s. 110.

${ }^{7}$ K. Romaniuk, Wiara w Zmartwychwstanie, Niepokalanów 1993, s. 83-84.

${ }^{8}$ E. Kopeć, Historiozbawczy charakter Zmartwychwstania..., s. 110. 
mocy świadczyło przywołane trzęsienie ziemi. Wyjście Chrystusa z grobu było wynikiem Jego tryumfu nad śmiercią, który dał Mu wszelką władzę na niebie i na ziemi, oraz spowodował stałą obecność wśród swoich uczniów. O niewiastach, które znalazły pusty grób, ewangelista pisał, że oddaliły się z bojaźnią i z wielką radością. Owa radość miała z pewnością związek z oświadczeniem anioła, że Chrystus zmartwychwstał. Święty Marek pozostał wierny swej chrystologii do końca utworu, głosząc nieustanną obecność Zbawiciela9

W Ewangelii św. Łukasza mieszczą się cztery wątki związane z wydarzeniami paschalnymi: odwiedziny grobu i angelofania $(24,1-12)$, chrystofania w drodze do Emaus (24,13-35), chrystofania w Wieczerniku (24,36-49) oraz wniebowstąpienie Chrystusa (24,50-52). W relacji wyraźnie zaakcentowana została bezradność niewiast z powodu widoku pustego grobu. Dzięki wyjaśnieniu dwóch mężczyzn, wysłanników Boga, dowiedziały się one o Boskim zmartwychwstaniu. W Ewangelii mowa, iż pochyliły się twarzami ku ziemi, co mogło być wyrazem szacunku, jaki chciały im oddać. Przypomniały sobie zarazem, że Zbawiciel zapowiadał im to wydarzenie. $\mathrm{W}$ ten sposób uświadomiły sobie, że na próżno szukały Go w grobie. O przypomnieniu sobie przez niewiasty zapowiedzi męki i zmartwychwstania Jezusa czyni wzmiankę tylko św. Łukasz. Według ewangelisty, one same, z własnej potrzeby, powiedziały jedenastu apostołom i pozostałym uczniom, co przeżywały przy pustym grobie. Wśród trzech niewiast, obecnych przy męce i ukrzyżowaniu Chrystusa, zamiast przywołanej przez św. Marka Salome, pojawiła się Joanna. Pusty grób zobaczyły także inne kobiety. Zwiększoną ich liczbę rozumieć należy w znaczeniu umocnienia prawdopodobieństwa ich zeznań ${ }^{10}$. Słowa niewiast usłyszane przez apostołów i innych ludzi ,zdały się im jako plotki [...], i nie wierzyli im" (Łk 24,11). Relację o pustym grobie usłyszeli apostołowie, jednak decyzję udania się do grobu Chrystusa podjął tylko św. Piotr, co świadczyło o świadomości roli, jaką miał do spełnienia, oraz o szacunku wobec niewiast (nie zlekceważył on przekazanych przez nie wiadomości). Jednak fakt pustego grobu nie wywołał w nim myśli, iż Jezus zmartwychwstał. Postawa zdziwionego Piotra była zbliżona do bezradności kobiet. Pusty grób zobaczyli także niektórzy uczniowie Chrystusa, jednak fakt ten nie był dla nich oznaką, że Chrystus zmartwychwstał. Akt wiary wymagał łaski Bożej, czego wyrazem było w Ewangelii posłannictwo dwu mężczyzn, chrystofanie oraz działanie Ducha Świętego, szczególnie widoczne podczas spotkania Jezusa przez uczniów w Emaus.

W Ewangelii św. Jana przedstawione zostały sceny: niewiasty u grobu, św. Piotr oraz św. Jan u grobu (20,-18), spotkanie Marii Magdaleny z Chrystusem, chrystofania w Wieczerniku i scena z niewiernym Tomaszem $(20,19-29)$.

\footnotetext{
9 Tamże, s. 111.

${ }^{10}$ K. Romaniuk, dz. cyt., s. 86.
} 
Przywołanej w Ewangelii Marii Magdalenie, która z żalem oznajmiła: „Wzięto Pana z grobu, a nie wiemy, gdzie Go położono" $(20,2)$, przez myśl nie przeszło, że Chrystus zmartwychwstał. Stojąca przed grobem i płacząca Maria Magdalena oznajmiła dwóm aniołom, że rozpaczała z powodu zabrania Jezusa z Jego grobu. Zwróciła się ona do Niego, którego wzięła za ogrodnika, z pytaniem, gdzie jest Jego ciało. Jedno Jego słowo („Mario”) sprawiło, że odkryła w Nim Zmartwychwstałego i przestała się smucić.

Święty Jan, podobnie jak święty Łukasz, wymienił jeszcze innych świadków pustego grobu: Piotra i Jana. Jednak spośród wszystkich czterech relacji o pustym grobie tylko na podstawie Ewangelii św. Jana można wywnioskować, iż „stwierdzenie faktu pustego grobu dało początek wierze w zmartwychwstanie Jezusa”"11. Apostoł stwierdził: „Natenczas tedy wszedł i on uczeń, który był pierwszy przyszedł do grobu: i widział, i uwierzył" $(20,8)$.

W zmartwychwstaniu Chrystusa, udokumentowanym świadectwami czterech ewangelii, podkreśla się jego realny (wydarzeniowy) i eschatyczny charakter $^{12}$. Jest ono wszechpotężnym aktem Bożej aktywności, za którego pomocą ukrzyżowany Chrystus ze stanu śmierci przeszedł do nowego życia nadprzyrodzonego. Jako „wydarzenie eschatyczne, nadprzyrodzone, przekracza kategorię faktu historycznego [...], niemniej zostało zamanifestowane w ziemskiej historii przez znaki: chrystofanii i pustego grobu, które stanowią jego historyczne uzasadnienie"13.

Oprócz ewangelii, wzmianki o zmartwychwstaniu Chrystusa występują w Dziejach Apostolskich i Listach św. Pawła, różne jednak od relacji z ewangelii. Tamte bowiem zawierały opisy objawień Chrystusa, zaś Dzieje Apostolskie ukazywały relacje o zmartwychwstaniu zazwyczaj w mowach apostołów, skierowanych do Żydów lub pogan. Apostołowie wykazali, że śmierć i zmartwychwstanie Mesjasza były w planach Bożych. Święty Paweł zaś zazwyczaj analizował ten fakt teologicznie ${ }^{14}$, podkreślając zbawczy charakter Chrystusowego zmartwychwstania ${ }^{15}$.

Temat zmartwychwstania Pańskiego podejmowany był przez twórców doby staropolskiej. Już w średniowieczu przedstawiono go w tak zwanej pieśni wielkanocnej, dołączonej do Bogurodzicy w XV wieku. To trop do końcowego Alleluja $\mathrm{z}$ łacińskiej antyfony procesyjnej Cum rex gloriae, traktującej o zstąpieniu

11 Tamże, s. 90.

12 Zob. E. Kopeć, Historiozbawczy charakter Zmartwychwstania..., s. 113.

13 Tamże, s. 113.

14 J. Frankowski, Zmartwychwstanie Chrystusa, „Znak”, R. 13: 1961, nr 7-8, s. 1001.

${ }^{15}$ M. Brzozowski, Z dziejów przepowiadania tajemnicy paschalnej, „Roczniki Teologiczno-Kanoniczne" 1971, t. 18, z. 3, s. 99. 
Chrystusa do otchłani, a śpiewanej podczas rezurekcji w Wielką Sobotę ${ }^{16}$. Tematyka wielkanocnych tropów rezurekcyjnych podjęta została w średniowiecznych tropach wielkanocnych. Najstarszy, zachowany przekaz polskiego tropu Chrystus z martwych wstat jest (Krystus z martwych wstat je) zapisany został przez Świętosława z Wilkowa w zaginionym dziś Graduale płockim z 1365 roku. Innym polskim tropem wielkanocnym jest Przez twe święte z martwy wstanie, który powstał prawie równolegle z tak zwaną wielkanocną pieśnią z Bogurodzicy albo nawet wcześniej ${ }^{17}$. Jerzy Woronczak trop Przez twe święte z martwy wstanie łączył z innym tropem rezurekcyjnym, Wesoly nam dzień nastał, dostrzegając w utworach te same źródła ${ }^{18}$. Polska redakcja tropu Wesoły nam dzień nastat pochodzi prawdopodobnie z XV wieku i jest parafrazą łacińskiego tropu $O$ quam felix haec dies ${ }^{19}$.

Tematykę wielkanocną ukazują także średniowieczne pieśni misteryjne ${ }^{20}$, zawierające wierszowane historie apokryficzno-biblijne. Z okresu średniowiecza pochodzi jeden utwór tego typu, mianowicie pieśń o incipicie Nasz Zbawiciel, Pan Bóg Wszechmogacy, której głównym wątkiem było zstąpienie Chrystusa do otchłani po zmartwychwstaniu. Znamienną cechą tej pieśni, na co zwrócił uwagę Mirosław Korolko, było przemieszanie wątków apokryficznych z ewangelicznymi. Do tematów, jakie podjęte zostały w utworze, należały, obok zstąpienia Zmartwychwstałego do otchłani, rozmowa Chrystusa z Marią Magdaleną i innymi niewiastami oraz chrystofania, czyli spotkanie Zmartwychwstałego z Matką ${ }^{21}$.

Zainteresowanie problematyką rezurekcyjną odzwierciedlają dwa utwory: Pieśń o Zmartwychwstaniu Pańskim: Wesel się tej to chwile, ludzkie pokolenie [...] oraz Krystus Pan zmartwychwstat, zwycięstwo otrzymat [...] (Kraków 1558), których autorstwo przypisywane jest Jakubowi Lubelczykowi (1530-1567), pisarzowi, tłumaczowi i poecie, polskiemu działaczowi reformacyjnemu, pastorowi kalwińskiemu, choć pewne adnotacje (krypt. J.L. na karcie tytułowej oraz Jak. Lub. na k. A4r.) wyraźnie odnoszą się tylko do pieśni drugiej. Druk ten jest częścią kancjonału składanego, zwanego Kancjonałem Zamoyskich ${ }^{22}$.

${ }^{16}$ M. Korolko, Wstęp, w: Średniowieczna pieśń religijna polska, oprac. M. Korolko, wyd. 2 zmien., Wrocław 1980, s. XXXI-XXXII.

17 Tamże, s. XXXIV.

18 J. Woronczak, Tropy i sekwencje w literaturze polskiej do połowy XVI wieku, „Pamiętnik Literacki”, R. 43: 1952, z. 1-2, s. 364-365.

${ }^{19}$ Istnieją także przekazy niemieckie pieśni z XIV wieku oraz późniejsze parafrazy w języku czeskim. Pisał o tym M. Korolko, dz. cyt., s. XXXVI-XXXVII.

${ }^{20}$ Zob. G. Ryś, Dwa oblicza polskiej religijności ludowej w średniowieczu, „Saeculum Christianum" 3, 1996, nr 1, s. 45.

${ }^{21}$ M. Korolko, dz. cyt., s. XLVII.

${ }_{22}$ Zob.http://www.europeana.eu/portal/pl/record/92033/BibliographicResource_3000053558954. html; http://cyfrowe.mnk.pl:8080/dlibra/docmetadata?id=779\&from=pubindex\&dirids=19\&lp=636. 
Średniowieczne misterium pozostawało żywotne jeszcze w pełni epoki odrodzenia. W Historyi o chwalebnym Zmartwychwstaniu Pańskim (Kraków 1582) Mikołaja z Wilkowiecka (zm. 1601) znajdujemy przedstawienia ewangelicznych scen wyjścia Chrystusa z grobu i odkrycia pustego miejsca przez niewiasty, ukazania się Chrystusa apostołom oraz istotę zbawczego sensu zmartwychwstania. Dzięki nakreślonym wątkom fabularnym utwór unaocznia „,szereg dogmatów i prawd wiary, o zmartwychwstaniu przede wszystkim i boskiej naturze Chrystusa"23. Problematykę tę ukazuje także powstały przed Wielkanocą 1676 roku barokowy Dialog o Zmartwychwstaniu Pańskim Wacława Potockiego ${ }^{24}$.

Przedmiotem niniejszego artykułu jest analiza zmartwychwstania Chrystusa, omówienie zakresu tematycznego oraz sposobów prezentacji treści objawieniowo-zbawczych w oparciu o cykl medytacji o zmartwychwstaniu Pańskim, zamieszczony w Kontemplacyi męki i śmierci Chrystusa Pana ${ }^{25}$. W tym celu wskazane zostaną w porządku chronologicznym sceny towarzyszące temu wydarzeniu: zstąpienie Chrystusa do piekieł, wyjście z grobu i odkrycie pustego grobu przez niewiasty, chrystofanie, dodatkowo - tylko wybrane, przejrzyste teologicznie przykłady scen łączących się ze zmartwychwstaniem. Z przekazów norbertańskich, co będzie można zaobserwować, wynika wartość poznawcza prawd wiary, oddziaływająca na sferę duchowo-intelektualną odbiorcy, pomagająca mu w refleksji nad historią zbawienia, ponadto ułatwiająca kontemplację prawd zbawczych.

Kontemplacyja męki i śmierci Chrystusa Pana i Odkupiciela naszego ku naśladowaniu i używaniu dusze nabożnej z inszemi bardzo uciesznemi wedtug czasu

${ }^{23}$ J. Okoń, Wstęp, w: Mikołaj z Wilkowiecka, Historyja o chwalebnym Zmartwychwstaniu Pańskim, oprac. J. Okoń, Wrocław 2004, s. XXXVI.

${ }^{24}$ Według J. Dürr-Durskiego, dialog powstał przed Wielkanocą 1673; fragmenty ogł.: A. Brückner, Spuścizna rękopiśmienna po W. Potockim, cz. 1, „Rozprawy Wydział Filologiczny AU” 1898, t. 27, s. 280-286; R. Pollak Ilustrowany Kurier Polski 1948, nr 86; całość wyd. M. Krzymuska i W. Budziszewska, Poznań 1949, Poznańskie Towarzystwo Przyjaciół Nauk, Zabytki Języka i Literatury Polskiej, nr 1; rękopis przechowywany jest w Bibliotece Kórnickiej, sygn. 494 IV 20 k. 18-35; kopia Ossol., sygn. 1823/II; epilog również w rękopisie w posiadaniu J. Dürr-Durskiego (dedykowany Helenie z Ossolina Lubomirskiej, wojewodzinie krakowskiej).

${ }^{25}$ Na temat medytacji o zmartwychwstaniu Pańskim, lecz w odniesieniu do konceptystycznego obrazowania, piszę w monografii: Perswazja w wybranych medytacjach siedemnastowiecznych z klasztoru norbertanek na Zwierzyńcu, Łódź 2016, s. 321-335. W książce wykazuję, że anonimowa autorka cyklu medytacji posługiwała się konceptem jako formą argumentu biblijnego, dzięki któremu zamierzała klarownie naświetlić podstawowe prawdy wiary, poruszyć adeptki i przekonać do kształtowania właściwych postaw. W niniejszym artykule, zmienionym i poszerzonym o relację zmartwychwstania w Biblii oraz w literaturze staropolskiej, zwracam uwagę przede wszystkim na walor poznawczy zaprezentowanego wydarzenia, a także na warstwę emocjonalno-intelektualną nadawcy, jego głębię wiary i życia religijnego. 
kontemplacyjami i naukami to kodeks rękopiśmienny z 1662 roku, przechowywany w Archiwum Norbertanek Zwierzynieckich. Manuskrypt składa się z siedmiu częśsi ${ }^{26}$. W pierwszej z nich, opatrzonej tym samym tytułem co cały kodeks (Kontemplacyja męki i śmierci Chrystusa Pana [...]), zamieszczone zostały medytacje o zmartwychwstaniu Pańskim. Cały kodeks pisany był różnym charakterem pisma, przez wiele autorek ${ }^{27}$. Wolno wysunąć tezę, że były nimi zakonnice klasztoru zwierzynieckiego. Natomiast rozważania o zmartwychwstaniu zapisano jednolitym charakterem pisma, co wskazywałoby na jedną ich twórczynię.

Na przedniej okładce manuskryptu widnieją inicjały (u góry Z.U., poniżej N.Z.S.), które odsyłają do Zofii Urbańskiej (ok. 1642-1717), ksieni zwierzynieckiej $^{28}$. Sugerują one, że zakonnica mogła oprawić rękopis do swojego użytku. Wysunąć należy też hipotezę, że Zofia Urbańska była jedną z autorek rozmyślań. Mogło być również tak, że współsiostry pisały rozmyślania (bądź je przepisywały), a potem ofiarowały je matce przełożonej w darze.

Cykl dwunastu medytacji o zmartwychwstaniu Pańskim opatrzony został tytułami: Pierwsza o wesolym tryumfie Pana uwielbionego; Medytacyja jako sie pokazat po zmartwychwstaniu Matce swojej; Medytacyja jako się Chrystus Pan zmartwychwstały Matce swej pokazat, czego figura może być gołębica; Medytacyja jako Chrystus Pan przy zmartwychwstaniu byt jako stonce; Medytacyja o zmartwychwstaniu, w którym byt Chrystus Pan jako kwiat; Medytacyja jako Anioł opowiedziat Zmartwychwstanie Pańskie białogłowom, o czym Ewangelia niedzielna; Medytacyja jakie przy Zmartwychwstaniu Pańskim pociechy panie wzięty, nawiedzajac grób Jego, o czym Ewangelia niedzielna; Medytacyja jako Pan po zmartwychwstaniu zgromadzat ucznie swoje, o czym Ewangelia na Poniedziałek Wielkanocny; Medytacyja jako Pan po zmartwychwstaniu częstowat ucznie swoje, o czym Ewangelia wtorkowa; Medytacyja z doktora jednego o św. Magdalenie jako szukała Pana, u Jana św., cap. 20; Medytacyja jako się Pan

${ }^{26}$ Piszę na ten temat w monografii Perswazja w wybranych medytacjach ..., s. 52.

${ }^{27}$ K. Górski zasygnalizował, że w rozmyślaniach klasztornych (pisały je benedyktynki reformy chełmińskiej, później za ich wzorem poszły norbertanki, cysterki i bernardynki) czasem jeden oprawny rękopis pisany był różnymi charakterami pisma, ,jakby zakonnice podzieliły między siebie okresy roku kościelnego". Zob. K. Górski, Uwagi o rozmyślaniach staropolskich, w: Przełom wieków XVI i XVII w literaturze i kulturze polskiej, red. B. Otwinowska i J. Pelc, Warszawa 1984, s. 223.

${ }^{28}$ Zofia Urbańska, córka Jana herbu Nieczuja oraz Katarzyny Dąbrowskiej z Rokszyc, nowicjat przyjęła w 1659 r., profesję złożyła w 1662 r. (ten sam rok widnieje na karcie tytułowej Kontemplacyi). W 1687 r. wpisana została do bractwa św. Zofii. Do roku 1694 była przeoryszą przy ksieni Oraczowskiej. Nie wybrano jej wówczas na ksienię z powodu jej surowości. Była nadal przeoryszą i sprawowała rządy przy ksieni Zbijewskiej. Dopiero po śmierci tej zakonnicy (1695) Urbańską obrano ksienią. Zmarła w 1717 r. - zob. K. Kramarska-Anyszek, Dzieje Klasztoru PP. Norbertanek w Krakowie na Zwierzyńcu do roku 1840, „Nasza Przeszłość” 1977, t. 47, s. 93-97, 104; M. Borkowska OSB, Leksykon zakonnic polskich epoki przedrozbiorowej, t. 2: Polska centralna i południowa, Warszawa 2005, s. 477. 
w osobie ogrodnika pokazat Magdalenie św. oraz Medytacyja jako się Pan Magdalenie św. pokazat.

Są to medytacje jedno-, dwu- i trzypunktowe, którym przyświeca zasadniczy cel: potrzeba unaocznienia prawd wiary i pobudzenia adeptek do religijnego ich przeżywania. Przekazy te, oparte przede wszystkim na ewangeliach, skoncentrowane zostały wokół jednego tematu, zmartwychwstania Chrystusa, przedstawianego z kilku punktów widzenia, w rozczłonkowaniu na części składowe.

W medytacji Pierwszej o wesołym tryumfie Pana uwielbionego autorka odwołała się do znanego z apokryfów wydarzenia - Chrystusowego zstąpienia do piekieł. Nakłaniała do rozważania zwycięstwa Zbawiciela wracającego ,z podziemnych krain" (p. 1) ${ }^{29}$, z których wyprowadził On dusze czekające na Jego przyjście. Chrystus, zstępując do piekieł, wyzwolił uwięzione dusze sprawiedliwych, „które oczekiwały swego Wyzwoliciela na łonie Abrahama” (KKK §633; por. Katechizm rzymski, t. 1, rozdz. 6, podrozdz. 3). Kraina zmarłych, do której zstąpił Syn Boży po śmierci, w Biblii nazwana jest piekłem, Szeolem lub Hadesem (por. Flp 2,10; Dz 2,24; Ap 1,18; Ef 4,9).

Ukazanie się zmartwychwstałego Chrystusa Matce to wydarzenie opisane w dwu przekazach: Medytacyi jako się pokazat po zmartwychwstaniu Matce swojej oraz Medytacyi jako się Chrystus Pan zmartwychwstaty Matce swej pokazat, czego figura może być gołębica. Relacji z tego zdarzenia brak w Piśmie Świętym. Najdawniejsza jednak tradycja Kościoła, sięgająca czasów Seduliusza (zm. $450)^{30}$, głosi, że Chrystus zaraz po wyjściu z grobu ukazał się w blasku zmartwychwstałego życia przede wszystkim swojej Matce. Była Ona zatem pierwszą osobą, której objawił się zmartwychwstały $\mathrm{Syn}^{31}$.

W rozważaniach zaakcentowano aspekt przynależności (unitio) Matki do Syna, która powinna współodczuwać (compassio) boleść Chrystusa Ukrzyżowanego, a także wesele wynikające ze zmartwychwstania. Do opisania radości Maryi, nazwanej „plastrem miodu Samsona”, posłużył norbertance przykład zwycięskiego Samsona z Księgi Sędziów, w którym zakonnica dostrzegła analogię do Chrystusa tryumfującego nad śmiercią i szatanem. Starotestamentowy bohater, jako wybrany przez Boga i obdarzony niezwykłą siłą, rękoma rozerwał lwa i w jego wnętrzu (paszczęce) znalazł rój pszczół i miód (Sdz 14,8). Pożerają-

${ }^{29}$ Wszystkie cytaty pochodzą z kodeksu Kontemplacyja męki i śmierci Chrystusa Pana i Odkupiciela naszego ku naśladowaniu i używaniu dusze nabożnej z inszemi bardzo uciesznemi wedtug czasu kontemplacyjami i naukami. Pisana Roku Pańskiego 1662, rkps ANZ, sygn. 594 (brak paginacji). Skrót p. odsyła do punktu medytacji.

${ }^{30}$ Zob. Sedulius Caelius, Poemat paschalny V, w: Tenże, Opera omnia. Dzieła wszystkie. Tekst łacińsko-polski, przekł., wstęp H. Wójtowicz, Lublin 1999, s. 213.

${ }^{31}$ Zob. św. I. Loyola, Pisma wybrane. Komentarze, oprac. M. Bednarz SJ, przy współpr. A. Bobera SJ, R. Skórki SJ, t. 2, Kraków 1968, s. 166; Jan Paweł II, Maryja a zmartwychwstanie Jezusa Chrystusa, w: Tenże, Katechezy Maryjne, przekł. J. Pach, Częstochowa 1998, s. 224. 
cy swoją ofiarę lew stał się obrazem śmierci, z której rodzi się nowe życie. Miód zatem to symbol życia, zaś plaster miodu wskazuje na zmartwychwstanie ${ }^{32}$.

W Medytacyi jako się Chrystus Pan zmartwychwstały Matce swej pokazat, czego figura może być gotębica zamieszczono rozważania na temat wymowy „płaczu” Maryi z powodu Chrystusowej męki, porównanego do opisanego w Księdze Rodzaju potopu. Oparte na figurze distinctio ${ }^{33}$ obrazowanie (,potop [...] wód wielkich smętek i płacz po śmierci Syna Matki Naświętszej”; „O, potopie łez, któryś tak zatopił oczy Panieńskie?") służyło zintensyfikowaniu bólu Maryi. Jej zapłakane oczy przyrównane zostały także do przedstawionych w Pieśni nad Pieśniami dwu sadzawek przy bramie w Hesebonie („O, jakie oczy Twoje, kiedyś rozmyślała śmierć Syna Twego. O, jako wiele wód te sadzaweczki miały"; p. 1). Opisani w Biblii, przybywający ze stepów ludzie, pili z owych zbiorników i myli się w nich („Oczy twoje jako sadzawki w Hesebonie”; PnP 7,4). W sensie metaforycznym oczy Oblubienicy, porównane z mieniącą się powierzchnią sadzawek, działały na tłum, w szczególności jednak na ukochanego ${ }^{34}$. Modlitwa błagalna o posiadanie „strumyczków oczu łez”, będących rezultatem kontemplacji Chrystusowej męki, wieńczy punkt pierwszy medytacji.

W Medytacyi jako Chrystus Pan przy zmartwychwstaniu byt jako stońce, opartej na podobieństwie, wyrażone zostało pragnienie doświadczenia „blasku” Zbawiciela. Wyartykułowano zarazem podziw wobec Jego piękna:

O, duszo moja, byś mogła dojzreć jaki promień tej śliczności. Wspomni, co ono jeden mówił z apostołów, kiedy się trochę błysnęła ta piękność w oczach jego. O, jako żadnej rzeczy na świecie już nie pragnął więcej, jeno żeby mieszkał przy takiej piękności i mówił: „Panie, dobrze nam tu”. O, śliczności, która serca ludzkie przenikasz (Medytacyja jako Chrystus Pan przy zmartwychwstaniu byt jako stońce, p. 1).

W przywołanym fragmencie wyraźnie nakreślona została potrzeba uobecnienia Chrystusa oraz postawa gotowości poznania. Wskazane za pomocą synonimicznych określeń piękno (,śliczność” i „piękność”) odsyła poprzez peryfrazę do osoby samego Chrystusa ${ }^{35}$. Autorka odwołała się do słów Szymona Piotra, który na Górze Przemienienia Pańskiego pełen zachwytu odezwał się do Jezusa: „Panie, dobrze jest nam tu być” (Mt 17,4). Podczas przemienienia na górze Tabor

${ }^{32}$ Hasło: Miód, w: M. Lurker, Stownik obrazów i symboli biblijnych, przekł. K. Romaniuk, Poznań 1989, s. 123.

${ }^{33}$ Figura distinctio polega „na powiększeniu semantycznej dystynkcji pomiędzy zwykłym (codziennym) znaczeniem pierwszego użycia słowa a emfatycznym/gruntownym znaczeniem przy drugim użyciu tego samego słowa" - zob. H. Lausberg, Retoryka literacka. Podstawy wiedzy o literaturze, przekł., oprac. i wstęp A. Gorzkowski, Bydgoszcz 2002, § 660.

${ }^{34}$ O. Keel, Pieśń nad Pieśniami. Biblijna pieśń o miłości, przekł. B. Mrozewicz, Poznań 1997, s. 246.

${ }^{35}$ O pięknie Boskiego Oblubieńca mowa w PnP. 
oblicze Chrystusa jaśniało jak słońce, a „szaty Jego zstały się białe jako śnieg” (Mt 17,2). Zaakcentowany zwrot deiktyczny „tu”, odsyłający do góry Tabor, stał się „ekwiwalentem gestu”36, bezpośrednio wskazującym obiekt prezentacji i dzięki temu zmuszającym odbiorcę do percepcji wizualnej, przyjęcia postawy „widza" ${ }^{37}$.

W oparciu o topikę solarną skonstruowano także punkt trzeci medytacji, w którym za pomocą similitudo ${ }^{38}$ mówi się zarówno o zasięgu działania słońca, jak i zmartwychwstałego Chrystusa. Wizualizowany obiekt na niebie za pomocą promieni ogarnia cały świat, w pierwszej jednak kolejności - górne przestrzenie; podobnie Zmartwychwstały cały świat napełnił weselem, najpierw jednak ,czeladkę swoję, to jest miłe apostoły swoje”. Po części refleksyjnej, zawierającej przemyślenia na temat „wdzięcznych promieni” Boskich, którymi uradowane zostały ludzkie serca, następuje modlitewne westchnienie:

O, Panie mój, któż mię uweseli, jeżeli Ty nie będziesz chciał być weselem serca mego. Szczęśliwi, co się z śmierci Twojej smęcili, abowiem ci ze zmartwychwstania się Twego weselą (Medytacyja jako Chrystus Pan przy zmartwychwstaniu byt jako słońce, p. 3).

Medytacyja o zmartwychwstaniu, w którym byt Chrystus Pan jako kwiat, przesycona emblematyczną symboliką, traktuje o chwalebnym zmartwychwstaniu Chrystusa i o Jego podobieństwie do kwiatu. Wprowadzona do przekazu analogia (rosnący w ogrodzie kwiat oraz łączące się z Chrystusem wydarzenia zlokalizowane w tej przestrzeni: pojmanie w ogrodzie Oliwnym i grób, do jakiego został złożony przez dwu uczniów) służy wyartykułowaniu pragnień duszy - dotarcia do swego wnętrza, a zarazem do „ogrodu duchowego" Zbawiciela.

Jednopunktowa Medytacyja jako anioł opowiedziat Zmartwychwstanie Pańskie białogłowom, o czym Ewangelia niedzielna ukazuje wizerunek anioła, Boskiego wysłannika, który jako pierwszy obwieścił zmartwychwstanie. W Nowym Testamencie aniołowie reprezentują chwałę i potęgę Bożą, są wykonawcami woli Stwórcy i posłańcami skierowanymi do ludzi. Ich status jest wyraźnie dyspozy-

${ }^{36}$ Na temat „gestów fonicznych”, partykuł oraz zaimków deiktycznych jako narzędzi literackiej wizualizacji zob. H. Dziechcińska, Oglądanie i stuchanie w kulturze dawnej Polski, Warszawa 1987, m.in. s. 133-135; Taż, Parawizualność literatury staropolskiej jako element ówczesnej kultury, w: Stowo i obraz. Materiaty Sympozjum Komitetu Nauk o Sztuce Polskiej Akademii Nauk, Nieborów, 29 września-1 października 1977 r., red. A. Morawińska, Warszawa 1982, s. 102-103.

${ }^{37}$ B. Niebelska-Rajca, ,Enargeia” $i$,,energeia” $w$ teoriach literackich renesansu $i$ baroku, Warszawa 2012, Studia Staropolskie. Series Nova, t. 32, s. 160.

${ }^{38}$ Figura similitudo (podobieństwo) to argument per analogiam oraz contrarium (a contrario) - zob. H. Lausberg, dz. cyt., $\S ~ 422-423,843-847$. Figura contrarium (locus a contrario) oparta jest na przeciwieństwie (tamże, $\S \S 394,420,423$ ). 
cyjny, służebny ${ }^{39}$. W przekazie norbertanki nakłania się orantkę do uruchomienia imaginacji, a przy jej użyciu do odtworzenia sceny biblijnej:

Uważ, jakie to było Zmartwychwstanie Pańskie, o którym anioł do białogłów mówił: „Powstał Pan prawy od umarłych, nie masz Go tu, abowiem to zmartwychwstanie Pana było w ciele uwielbionym i nieśmiertelnym. W ciele zmartwychwstał, aby jako na ciele cirpiał i był poniżony, tak słuszna, aby też ciało Jego było wyniesione" (Medytacyja jako anioł opowiedział Zmartwychwstanie Pańskie białogłowom, o czym Ewangelia niedzielna, p. 1).

W Ewangelii św. Mateusza czytamy o aniele odsuwającym kamień z grobu oraz o otwarciu grobu jako o „szczególnie potężnym czynie nieba”40. O potędze Boga świadczy również zawarta w relacji Mateusza wzmianka o trzęsieniu ziemi, które spowodowane zostało tym, że anioł Pański odsunął kamień i triumfalnie usiadł na nim. Anioł Pański bez trudu otworzył drogę do grobu, w wyniku czego niewiasty mogły zobaczyć jego wnętrze. Trzęsienie ziemi było więc powiązane ze zstąpieniem anioła, który otwierał grób. Mateusz nazywał go aniołem Pańskim, zaś Marek mówił o młodzieńcu siedzącym po prawej stronie. Biała szata anioła oraz jasność jego postaci symbolizowały moc i chwałę Bożą, w której uczestniczył Zmartwychwstały ${ }^{41}$. Orantka, zachęcając do uruchomienia zmysłów wzroku i słuchu, pragnęła osiągnąć umiejętność kontemplowania pustego grobu oraz ,uwielbienia” Chrystusowego ciała:

Daj, Panie, abym była godna jako słyszeć, tak patrzyć z temi paniami na to uwielbienie ciała Twego. [...] O, Panie, poślij takiego anioła, który by mnie nauczył jako patrzyć mam w ten Twój grób (Medytacyja jako anioł opowiedział Zmartwychwstanie Pańskie białogłowom, o czym Ewangelia niedzielna, p. 1).

Medytacyja, jakie przy Zmartwychwstaniu Pańskim pociechy panie wzięty, nawiedzając grób Jego, o czym Ewangelia niedzielna przedstawia radujące się ze zmartwychwstania niewiasty. Podkreśla się w przekazie fakt wyłonienia przez Boga kobiet; im bowiem jako pierwszym obwieszczona została radosna nowina:

Uważać, że ta pierwsza pociecha ich była, kiedy przed innemi apostoły zmartwychwstanie im anioł obwieścił. Bieżcie, prawi, i opowiedzcie to uczniom i Piotrowi, że Chrystus zmartwychwstał (Medytacyja, jakie przy Zmartwychwstaniu Pańskim pociechy panie wzięły, nawiedzając grób Jego, o czym Ewangelia niedzielna, p. 1).

${ }^{39}$ F. M. Rosiński, Aniołowie w Nowym Testamencie, w: Anioł $w$ literaturze $i$ w kulturze, red. J. Ługowska, t. 2, Wrocław 2005, s. 20-21. Na temat aniołów w Nowym Testamencie zob. też: D. Künstler-Langner, Anioł w poezji baroku. Dzieje postaci w kulturze dawnej Europy, Torun 2007, s. 25-31; D. Dybek, Anioł w piśmiennictwie polskim XVII-XVIII wieku, Wrocław 2012.

${ }^{40}$ L. Scheffczyk, Zmartwychwstanie, przekł. P. Pachciarek, Warszawa 1984, s. 82.

${ }^{41}$ E. Wiszowaty, Zmartwychwstanie centrum chrześcijańskiego przepowiadania. Studium na temat perykop wielkanocnych Ewangelii Mateusza (28,1-20), Olsztyn 1998, s. 52. 
Według Ewangelii św. Mateusza, niewiasty przyszły do grobu nie po to, by, jak u Marka i Łukasza, namaścić ciało Jezusa, nie przyszły tam również opłakiwać zmarłego, lecz po to, by obejrzeć grób. Ukazanie się im anioła i przekazanie im wiadomości o zmartwychwstaniu uczyniło je wiarygodnymi wobec apostołów świadkami. Nawet jeśli nie były one w judaizmie za takie uważane, ,to jednak one jako pierwsze usłyszały wielkanocną nowinę i zostały wezwane do jej głoszenia"42. Wcześniej to one nie cofnęły się, idąc za Chrystusem aż pod krzyż. Wyraźnie pobrzmiewa w rozważaniach norbertanki idea wybrania przez Boga małych i słabych, która przenika całą Biblię ${ }^{43}$. Pierwszeństwo dane niewiastom uzasadnione zostało w następujący sposób: radość niewiast ze zmartwychwstania, podobnie jak niegdyś uradowanie Maryi ze zwiastowania, powinna stłumić smutek, będący wynikiem grzechu starotestamentowej Ewy.

Spotkanie Chrystusa z uczniami po zmartwychwstaniu to scena, do której nawiązuje Medytacyja jako Pan po zmartwychwstaniu zgromadzat ucznie swoje, o czym Ewangelia na Poniedziatek Wielkanocny, nakłaniająca do unaocznienia sytuacji związanych z tym wydarzeniem. W Ewangelii św. Mateusza opisane zostało ukazanie się zmartwychwstałego Chrystusa uczniom w Galilei (Mt 28,16-20), Marek przedstawił spotkanie Jezusa z dwoma uczniami w drodze do Emaus (Mk 16,12-13) oraz z jedenastoma apostołami w Jerozolimie (Mk 16,14; 16,15-18). W Ewangelii św. Łukasza czytamy o ukazaniu się Chrystusa uczniom z Emaus (Łk 24,13-35), apostołom (Łk 24,36-43) oraz uczniom w Jerozolimie (Łk 24,44-49), zaś Ewangelia św. Jana zrelacjonowała ukazanie się Chrystusa apostołom (J 20,19-23), niewiernemu Tomaszowi (J 20,24-29) i uczniom w Galilei (J 21,1-14).

Rozpoczynająca się od similitudo medytacja norbertanki („Abowiem naprzód jako kokosz zgromadza kurczęta pokarmem abo ziarnem, tak i Chrystus Pan chlebem swoim niebieskim") odsyłała do znanych z Ewangelii św. Mateusza słów Chrystusa, spoglądającego na zaślepione w grzechach miasto (Mt 23,37). Nawiązanie do relacji Łukasza o łamaniu przez Chrystusa chleba i rozpoznaniu Go przez uczniów z Emaus (Łk 24,30-31) służyło w medytacji głębszej refleksji nad grzeszną naturą człowieka oraz Boskim miłosierdziem (p. 1).

W punkcie drugim medytacji, zaczynającym się od similitudo („Kokosz kurczęta do siebie wabi ciepłem pod skrzydła, toż i Chrystus Pan czyni”), tematem rozważania stało się „serce” uczniów z Emaus, które zapałało do Chrystusa ogniem miłości. Nie pałało ono jednak do Niego, jak podkreśliła autorka, kiedy uczniowie byli w drodze (por. Ł 24,32). W części refleksyjnej zamieszczona została prośba orantki, skierowana do Boga, o rozgrzanie jej chłodnego serca: „O, serce moje, jakoś lodowate. [...] Proszę, użycz ognia tego Twego na roz-

\footnotetext{
42 Tamże, s. 61.

${ }^{43}$ Por. 1 Kor 1,26-30.
} 
palenie serca mego, daj, aby we mnie zawsze gorzał" (Medytacyja jako Pan po zmartwychwstaniu zgromadzat ucznie swoje, o czym Ewangelia na Poniedziatek Wielkanocny, p. 2). W nawiązaniu do słów z Ewangelii św. Łukasza („Przyszedłem puścić ogień na ziemię, a czegoż chcę, jedno, aby był zapalon?”; Łk 12,49), uwydatnia się w przekazie potrzebę „rozpalenia” przez Chrystusa „lodowatego serca" ludzkiego. Mowa również, przy użyciu metaforyki przestrzennej, o geście wejścia Zmartwychwstałego wraz z uczniami do „ubogiej gospody serca”, które umożliwi przemianę w człowieku.

W Medytacyi jako Pan po zmartwychwstaniu częstowat ucznie swoje, o czym Ewangelia wtorkowa zaprezentowana została scena częstowania uczniów rybą. Autorka zalecała skupić się na znaczeniu symbolu ryby, odnoszącym się do samego Chrystusa (p. 1). Za pomocą similitudo (tak jak ryba z wody pochodzi, tak i Syn Boży w chwale i w ,pociechach pływał” zanim z nieba przyszedł na ziemię) wyeksponowała poświęcenie Chrystusa, który opuścił królestwo niebieskie i „zniżył się” do człowieka („O, jakoś się bez tych wód, pociech nalazł!”; p. 1). Uwydatniła zarazem odkupieńczą rolę męki Zbawiciela, będącej wyrazem Jego miłości do człowieka i troski o niego (,„[...] abyś ty pociech wiecznych zażywać mogła”; p. 1). W konkluzji rozważań, opartej na przeciwieństwie („Umiera ryba bez wody. Ty, Panie, i żyjesz, i umierasz bez pociech"; p. 1), nakreślone zostało położenie Chrystusa, odsuniętego od wszelkich radości.

Wydarzeniu zmartwychwstania Chrystusa towarzyszy także opisana w Ewangelii św. Jana chrystofania Marii Magdalenie ${ }^{44}$, która wczesnym rankiem udała się do grobu Zbawiciela i zobaczyła, że jest pusty. Do wizualizacji scen z jej udziałem zachęcają trzy ostatnie rozmyślania wielkanocne, zatytułowane kolejno: Medytacyja z doktora jednego o św. Magdalenie jako szukała Pana, u Jana św., cap. 20; Medytacyja jako się Pan w osobie ogrodnika pokazat Magdalenie świętej; Medytacyja jako się Pan Magdalenie świętej pokazat. O przyczynach żalu i płaczu niewiasty mowa w pierwszym przekazie (p. 1). Pokazane w nim zostały postawy: kobiety zatroskanej o Zbawiciela oraz Chrystusa, który płacz niewiasty wynagrodził łaskami.

Maria Magdalena szczególnie intensywnie przeżyła swoje spotkanie ze Zmartwychwstałym. Ujrzała Go, jednak nie rozpoznała, ponieważ wzięła Go za ogrodnika. Ta ewangeliczna relacja stała się przedmiotem Medytacyi jako się Pan w osobie ogrodnika pokazat Magdalenie św., przedstawiającej Chrystusa jako „ogrodnika serc ludzkich i dusz” (p. 1). Uwidoczniona została w rozmyślaniu analogia do fragmentu z Pieśni nad Pieśniami, w którym zapłakana Oblubienica szukała swego Oblubieńca (PnP 3,1-4), On zaś ukryty przed ukochaną pracował w ogrodzie jako ogrodnik (PnP 6,1-3).

${ }^{44}$ Zob. E. Krawiecka, Staropolskie portrety św. Marii Magdaleny, Poznań 2006. 
W postawie orantki nakreślona została jej gotowość otwarcia się na Boga przemieniającego ludzkie serce. Za pomocą toposu ogrodu oraz florystycznego obrazowania (ogród duszy, do którego zapraszany jest Chrystus-ogrodnik, by strzec w nim zamku i bramy, czyli ludzkiego jestestwa; szczepienie, szczepy, ziółka, rosa) wyrażono potrzebę duchowej transformacji. W modlitwie błagalnej skierowanej do Zbawiciela zamieszczono prośbę, by zatroszczył się o ,zakwitnięcie” w owym ogrodzie ziółek i szczepów, czyli wszelkich cnót człowieka.

Zachęta do rozważania radości Marii Magdaleny, która rozpoznała w Odkupicielu swego Nauczyciela, kiedy Ten zwrócił się do niej po imieniu, to temat podjęty w Medytacyi jako się Pan Magdalenie św. pokazał. Jej wesele było tym większe, iż szukając ciała zmarłego Chrystusa, znalazła Go żywego, jako zwycięzcę śmierci. Orantka, powołując się na słowa z Pieśni nad Pieśniami (,,[...] nalazłam Tego, którego miłuje dusza moja: / pojmałam Go i nie puszczę Go"; PnP 3,4), zwróciła się z prośbą do świętej Marii Magdaleny, by ubłagała u Boga łaski dla człowieka pragnącego przy Nim trwać:

O, Pani święta, uproś mi takiego nabożeństwa i radości iskierkę, niechaj też mówi dusza moja: nalazłam mego Umiłowanego, nie opuszczę Go więcej od siebie (Medytacyja jako się Pan Magdalenie św. pokazat, p. 1).

Rozradowanie Marii Magdaleny, jak czytamy w Piśmie Świętym, wiązało się także z decyzją Zmartwychwstałego o wybraniu jej na głosicielkę Jego orędzia skierowanego do „braci”, że wstępuje On do Boga. Autorka nakazywała więc rozważać Jego miłość i uniżoność wobec uczniów ze względu na nazwanie ich „braćmi”. Owocem medytacji jest przeżycie jedności ze światem i ludźmi, stąd orantka w swej medytacyjnej postawie pragnęła, za pośrednictwem Marii Magdaleny i „wszystkich braci”, oddać chwałę Zbawicielowi za Jego dostojeństwo.

Rękopiśmienne medytacje o Zmartwychwstaniu Pańskim zawierają rozważania między innymi o zstąpieniu do piekieł, triumfie uwielbionego Pana, o scenie wyjścia Chrystusa z grobu i odkryciu pustego grobu przez niewiasty, o scenie cudownego połowu ryb, o świadectwach chrystofanii. Zaprezentowane wątki uwydatniają szereg dogmatów i prawd wiary, przede wszystkim o zmartwychwstaniu Jezusa oraz o Jego Boskiej naturze.

Opisane przez norbertankę wydarzenia potwierdziły, że przejęła ona z ewangelii wiele sytuacji związanych ze zmartwychwstaniem. Pojawiły się w przekazie także egzempla o starotestamentowej proweniencji, które dowodzą swobodnego czerpania z tradycji biblijnej. Są także w medytacjach wątki (np. ukazanie się Chrystusa po zmartwychwstaniu swojej Matce oraz światu w postaci słońca czy kwiatu), o jakich ewangelie nie wzmiankują, a które przemawiają za tym, że autorka odwoływać się mogła do źródeł apokryficznych bądź do przedstawień 
emblematycznych. Wprowadzone wątki były świadectwem inwencji twórczej zakonnicy oraz indywidualnego sposobu budowania rzeczywistości unaoczniającej wydarzenia wielkanocne.

Przekazy anonimowej norbertanki zwierzynieckiej skierowane zostały do współsióstr tamtejszej społeczności, czyli do kompetentnych odbiorców, posiadających umiejętność rozumienia owych tekstów, ukierunkowanych na duchową przemianę. Zadaniem medytacji jest zjednoczenie sił po to, aby człowiek mógł wspiąć się na wyżyny świętości i całym swym sercem zwrócić się do Boga. Ta duchowa aktywność konieczna jest do pogłębienia wiary w celu poznania miłości Boga oraz zjednoczenia z Nim. Analizowane teksty, służące duchowemu doskonaleniu się oraz nawiązaniu relacji z rzeczywistością transcendentną, w pełni sytuują się w obszarze piśmiennictwa medytacyjnego.

\section{Resurrection of Christ in the manuscript of a Norbertine Sister from the Zwierzyniec convent, "The contemplation of the suffering and death of Christ, our Lord [...]" (1662)}

\section{Summary}

The subject of the article is the analysis of $17^{\text {th }}$ century meditations about the Resurrection of Christ included in the manuscript collection of the Norbertine Sisters in Zwierzyniec. The reflection covers the traditions about the triumph of the glorified Lord, the women's visit to the Lord's Tomb, the announcement of the Resurrection to the women, Christ offering fish to his disciples, Christ's meeting with Mary Magdalene and the disciples on their way to Emaus. The mode of presentation of these themes emphasizes a number of dogmas and truths of faith, mostly about the Resurrection of Christ and his divine nature. It is demonstrated in the article that the Norbertine texts were based not only on Gospels, but also on apocryphal sources and emblematic representations. The deliberations clarify that the author probably intended not only to report the course of events, but first of all to give a testimony of faith, to assert the real resurrection of the crucified Christ. An insight into the issue of the Resurrection of Christ in the light of biblical tradition and Old Polish literature is also offered.

\section{Keywords}

Resurrection of Christ, Norbertine Sisters' Meditations from the Zwierzyniec convent, $17^{\text {th }}$ century manuscript, Bible, Old Polish literature.

\section{Słowa kluczowe}

zmartwychwstanie Pańskie, medytacje norbertanek zwierzynieckich, rękopis z XVII wieku, Biblia, literatura staropolska. 


\section{Bibliografia}

Biblia w przekładzie ks. Jakuba Wujka z 1599 r., wstęp J. Frankowski, wyd. 5, Warszawa 2000. Borkowska M. OSB, Leksykon zakonnic polskich epoki przedrozbiorowej, t. 2: Polska centralna i poludniowa, Warszawa 2005.

Brzozowski M., Z dziejów przepowiadania tajemnicy paschalnej, „Roczniki Teologiczno-Kanoniczne" 1971, t. 18, z. 3, s. 97-112.

Celary I., Głoszenie wiary w zmartwychwstanie Chrystusa zasadniczym celem nowej ewangelizacji, „Wrocławski Przegląd Teologiczny”, R. 11: 2003, nr 1, s. 117-135.

Celary I., Prawda o zmartwychwstaniu w przepowiadaniu kaznodziejsko-homiletycznym, „Polonia Sacra”, R. 7 (25): 2003, nr 12/56, s. 125-138.

Dybek D., Anioł w piśmiennictwie polskim XVII-XVIII wieku, Wrocław 2012.

Dziechcińska H., Ogladanie i stuchanie w kulturze dawnej Polski, Warszawa 1987.

Dziechcińska H., Parawizualność literatury staropolskiej jako element ówczesnej kultury, w: Stowo i obraz. Materiaty Sympozjum Komitetu Nauk o Sztuce Polskiej Akademii Nauk, Nieborów, 29 września - 1 października 1977 r., red. A. Morawińska, Warszawa 1982, s. 97-112.

Frankowski J., Zmartwychwstanie Chrystusa, „Znak”, R. 13: 1961, nr 7-8, s. 1000-1010. Górski K., Uwagi o rozmyślaniach staropolskich, w: Przełom wieków XVI i XVII w literaturze i kulturze polskiej, red. B. Otwinowska, J. Pelc, Warszawa 1984, s. 223-228.

Granat W., Zmartwychwstanie Jezusa Chrystusa jako wydarzenie zbawcze, w: Jezus Chrystus. Historia i tajemnica, red. W. Granat, E. Kopeć, Lublin 1988, Rozprawy Wydziału Teologiczno-Kanonicznego, t. 81, s. 277-293.

Jan Paweł II, Maryja a zmartwychwstanie Jezusa Chrystusa, w: Tenże, Katechezy Maryjne, przekł. J. Pach, Częstochowa 1998.

Kaczor-Scheitler K., Perswazja w wybranych medytacjach siedemnastowiecznych z klasztoru norbertanek na Zwierzyńcu, Łódź 2016.

Katechizm Kościoła katolickiego, Poznań 1994.

Katechizm rzymski wedtug uchwały św. Soboru Trydenckiego dla plebanów utożony, z rozkazu najprzód Piusa V, potem Klemensa XIII po łacinie wydany, na polski język $w$ lat cztery po soborze przez ks. Walentego Kuczborskiego, archidiakona pomorskiego przetlumaczony, teraz zaś z małemi poprawkami i z niektóremi dodatkami przedrukowany, t. 1, Jasło 1866.

Keel O., Pieśn nad Pieśniami. Biblijna pieśń o miłości, przekł. B. Mrozewicz, Poznań 1997.

Kopeć E., Historiozbawczy charakter Zmartwychwstania Jezusa Chrystusa, „Roczniki Teologiczno-Kanoniczne" 1977, t. 24, z. 4, s. 107-118.

Kopeć E., Spotkanie św. Pawta z Chrystusem, „Zeszyty Naukowe KUL” 1960, t. 3, z. 1 (9), s. 45-60.

Kopeć E., Zmartwychwstanie Jezusa Chrystusa jako realny fakt $i$ wydarzenie zbawcze, w: Jezus Chrystus. Historia i tajemnica, red. W. Granat, E. Kopeć, Lublin 1988, Rozprawy Wydziału Teologiczno-Kanonicznego, t. 81, s. 246-277.

Korolko M., Wstęp, w: Średniowieczna pieśń religijna polska, oprac. M. Korolko, wyd. 2 zmienione, Wrocław 1980, s. III-LXXVI. 
Kramarska-Anyszek K., Dzieje Klasztoru PP. Norbertanek w Krakowie na Zwierzyńcu do roku 1840, „Nasza Przeszłość” 1977, t. 47, s. 5-169.

Krawiecka E., Staropolskie portrety św. Marii Magdaleny, Poznań 2006.

Künstler-Langner D., Anioł w poezji baroku. Dzieje postaci w kulturze dawnej Europy, Toruń 2007.

Léon-Dufour X., Sur la resurrection de Jésus, „Recherches de science religieuse”, 57: 1969, s. 583-622.

Lurker M., Słownik obrazów i symboli biblijnych, przekł. K. Romaniuk, Poznań 1989.

Nagy S. SCJ, Sakralny charakter niedzieli, „Communio. Międzynarodowy Przegląd Teologiczny", R. 2: 1982, nr 3, s. 17-25.

Niebelska-Rajca B., ,,Enargeia” $i$,,energeia” $w$ teoriach literackich renesansu i baroku, Warszawa 2012, Studia Staropolskie. Series Nova, t. 32.

Okoń J., Wstęp, w: Mikołaj z Wilkowiecka, Historyja o chwalebnym Zmartwychwstaniu Pańskim, oprac. J. Okoń, Wrocław 2004, s. V-CXVI.

Romaniuk K., Wiara w Zmartwychwstanie, Niepokalanów 1993.

Rosiński F.M., Aniołowie w Nowym Testamencie, w: Anioł w literaturze i w kulturze, red. J. Ługowska, t. 2, Wrocław 2005, s. 13-33.

Ryś G., Dwa oblicza polskiej religijności ludowej w średniowieczu, „Saeculum Christianum" 3, 1996, nr 1, s. 33-48.

Scheffczyk L., Zmartwychwstanie, przekł. P. Pachciarek, Warszawa 1984.

Sedulius C., Opera omnia. Dzieła wszystkie. Tekst łacińsko-polski, przekł., wstęp H. Wójtowicz, Lublin 1999.

Stefaniak L., Historyczność Zmartwychwstania Chrystusa w Listach św. Pawła, „Ruch Biblijny i Liturgiczny", R. 8: 1955, nr 6, s. 306-327.

Loyola I., św., Pisma wybrane. Komentarze, oprac. M. Bednarz SJ, przy współpr. A. Bobera SJ, R. Skórki SJ, t. 2, Kraków 1968.

Wiszowaty E., Zmartwychwstanie centrum chrześcijańskiego przepowiadania. Studium na temat perykop wielkanocnych Ewangelii Mateusza (28,1-20), Olsztyn 1998.

Woronczak J., Tropy i sekwencje w literaturze polskiej do połowy XVI wieku, „Pamiętnik Literacki”, R. 43: 1952, z. 1-2, s. 335-374. 
